49 酸素切断火口に關す石研究
木原博上田虎之助
狐塚泰治

\title{
Foundamental Experiments on Oxy-Accetylene Gas Cutting Torch
}

\author{
By H. Kihara,* \\ T. Ueda**
}

\begin{abstract}
The Purpose of this investigation was to compare working efficiency of divergent nozzle and straight nozzle. From the nature of divergent nozzle which is primarly designed by the amount of oxygen flow and the throat area, oxygen pressure of a given divergent nozzle has to be always kept at constant pressure. Therefore, experiments were carried out with each 2 sets of divergent and straight nozzles having design variables as shown below:

1) Oxygen pressure: $\quad 3.5 \mathrm{~kg} / \mathrm{mm}$.

Amount of oxygen flow : $27661 / \mathrm{hr}$

2) Oxygen pressure: $\quad 4.0 \mathrm{~kg} / \mathrm{mm}$.

Amount of oxygen flow: $38061 / \mathrm{hr}$.

Keeping othet factors at constant, structural steel of $12,20,25$ and $50 \mathrm{~mm}$ thickness were gas cutted with various cutting speed by both type of nozzles. Equal results were obtained by either type, that is, cutting speed at zero drag and maximum cutting. speed obtainable were found to be exactly equal. Since the amount of oxygen flow is diffrent; above result shows that the cutting afficiency of divergent nozzle is superior to that of straight nozzle. $27.4 \%$ of oxygen consumption can be saved by using divergent nozzle.

Ideal shape of divergent nozzle for different thickness of steel plate, that is, proper operating pressure and throat area are to be obtained through repeated and systematic investigaticn of this kind.
\end{abstract}

\section{1.まえな き}

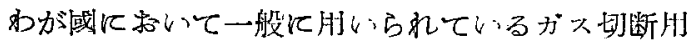

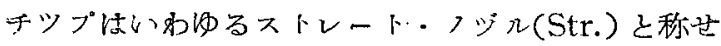

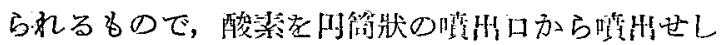

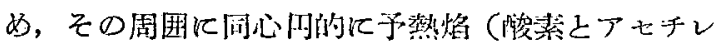
ンの混合ガス)を出すようにしたもので务。しか

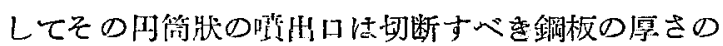

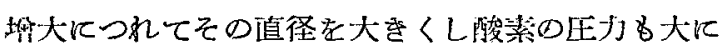

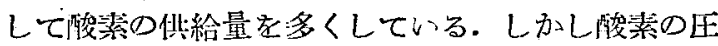

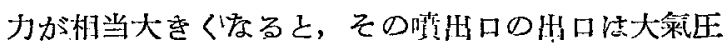

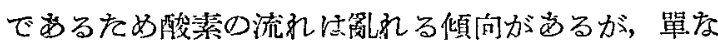
る内䇠形を特心机, 途中の直径を出口の直径より る適当に小さくしたものすなわちダイバーゼント・

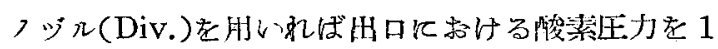

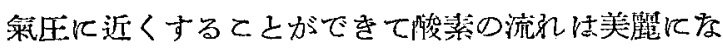

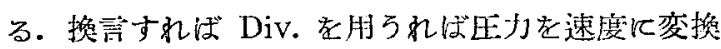
して美麗な酸素の流れが得られる牙断面は关啒にな

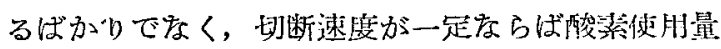

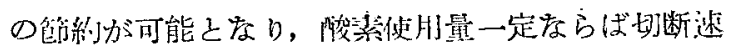

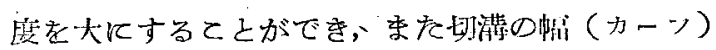
る小さくなし得るのでるる。

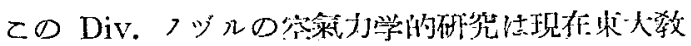

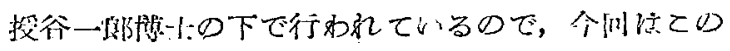
フッ゙ルの予備的奏驗結果のみを都告するに止める。

\section{2. 礰究方針及び實驗方法}

\section{1 一般}

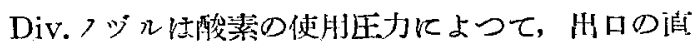
径に対する最小淔径部（スロートと㭔ぶ）の比が定 まり，徆素の流量によりスロートの值径が定まるの でする.從つて鋼板の厚さに應じて凌素の適当な流

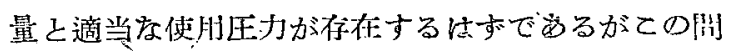
題を系統的任実驗研究する前に果して Div。フシれ

*** 正負, 大阪大学工学部 Member, Faculty of Engineering, Osaka University. 
は通常のStr.ノッ゙ルに比較して研究の対象になり得

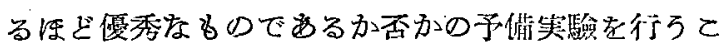
とにした. そこで厚さ $25 \mathrm{~mm} の$ 鋼板の排断に適する そ予想されるノッ゙ルをStr. 及びDiv.のるの冬々 1

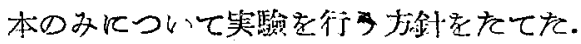

\section{2 調查}

この研究の立脚点を $25 \mathrm{~mm}$ 鋼板の切断におくため わが成の各造船所飞怙ける25mm 鋼板の包断飞関す

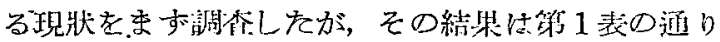
でめる。

第 1 表 我國造船所に於ける $25 \mathrm{~mm}$ 錨板 のがス切断に関する資料

\begin{tabular}{|c|c|c|c|c|c|c|c|}
\hline 造船 & 西日本 & $\begin{array}{l}\text { 中日本 } \\
\text { (动戶) }\end{array}$ & 旦章 & $\begin{array}{l}\text { 日立 } \\
\text { (櫻島) }\end{array}$ & 至瑟 & 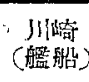 & $\begin{array}{l}\text { 浦架 } \\
\text { (浦賀) }\end{array}$ \\
\hline $\begin{array}{l}\text { 切断速寞 } \\
\mathrm{cm} / \mathrm{min}\end{array}$ & 210 & 200 & 200 & ' 310 & 350 & 240 & 200 \\
\hline 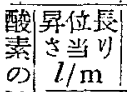 & 260 & 300 & 300 & - & - & 280 & 350 \\
\hline 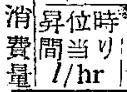 & 3270 & 3600 & 3600 & - & - & 4030 & 4200 . \\
\hline
\end{tabular}

\section{$2: 3$ 切断楼}

実䲆に際して怯手による切断を避け，自動ガス切 断機を採肘することにしを。“箺驗のねめにはチップ

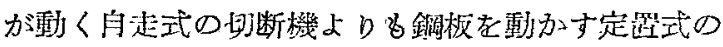

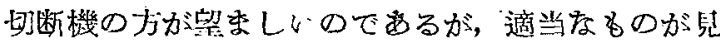

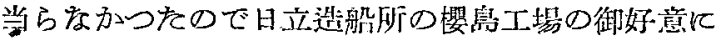

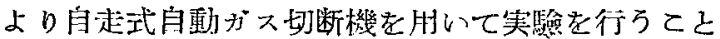
にした。

この自動切断機の減速力法怯ウォー正車之平歯 車 5 段によるもので䣕動輸怙片側のみでする。速度

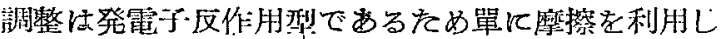
た他の型式のものに比し，速度調整け内滑でしが

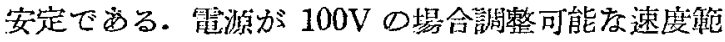

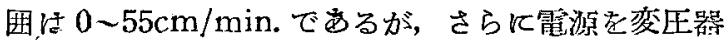

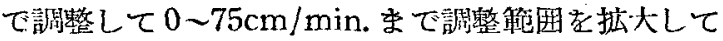

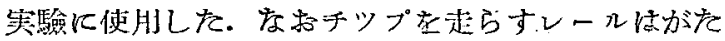
つきをなくるた为特に航製して実驗の正碓索期し t.

\section{4 ノジル}

(a) Str.ノッ゙ル-25mm 銅板を口径約 $1.3 \mathrm{~mm} の$

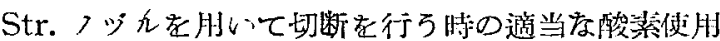

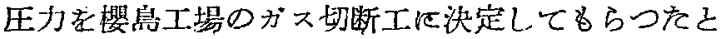
ころ， $4 \mathrm{~kg} / \mathrm{cm}^{2}$ 㥀を得たのでこの実驗に壮すべて この正力を探用することにした。後述するごよくこ

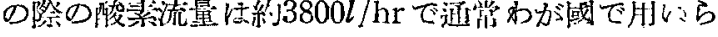

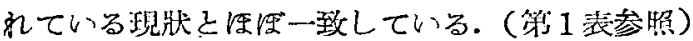

(b) Div. フッ゙れ-Div.ノジれはStr、ノッ゙ルよ

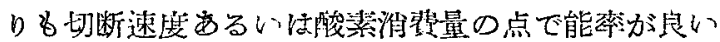

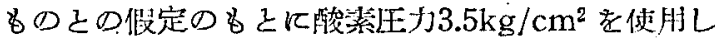

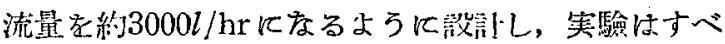
てての圧力を使㫭することにした。

\section{5 切断中の酸素圧力の保持}

Str.ノッ゙ル対して忙 $4 \mathrm{~kg} / \mathrm{cm}^{2}$, Div.ノッ゙れに対 しては $3.5 \mathrm{~kg} / \mathrm{cm}^{2}$ 佂力常飞保持するために，

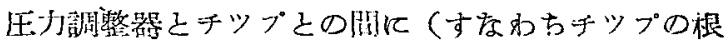

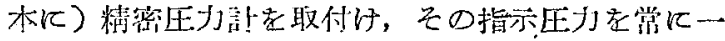

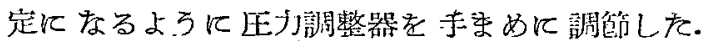
しかしてその精密区力部の指示老規定压力の士0.1 $\mathrm{kg} / \mathrm{cm}^{2}$ の籍团內儿保持するとさができた。

\section{6 予熱焰及チツプと鋼板との距離}

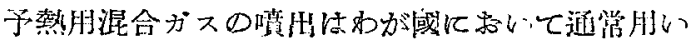
られている形狀す存わち酸素梖出口之同心円的度形

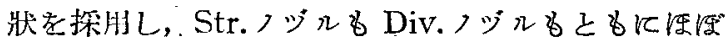
闹一の予熱焰を开し得るよらにした。そしてチップ

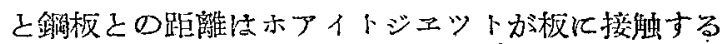
程度すを存わち約 $4 \mathrm{~mm}$ 保持した。

\section{7 酸素の純度}

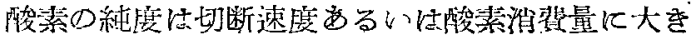
な影響を捇つているので，実驗に使用する酸素は使 用前に各ボンべでとに分析老行い，99.3〜99.5\%の。 筑囲のもののみを为いを。

\section{8 鋼板}

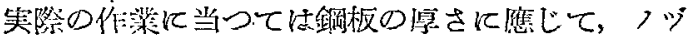

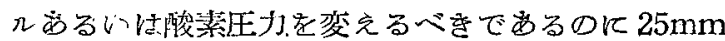

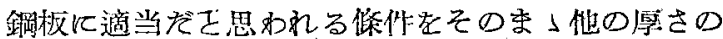

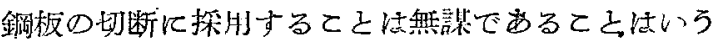

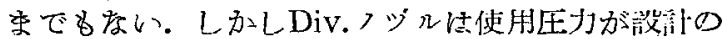
時加方定つているのですつて鋼板の愿さに應じて压

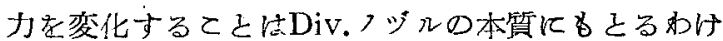
である。從つてDiv.フッ゙ルと Str.ノッ゙の比較をす るのがこの実驗の啲でする以上，Str.フッ゙の压

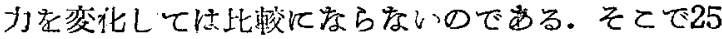

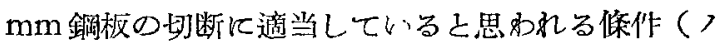
ッ゙ルの口の压力）を常に一起に保ちながら，でき るだけ多くの各整の厚さの鋼板を切断速度のみ変 化して笑驗を行つてみるととにした。すをわち 12 ，

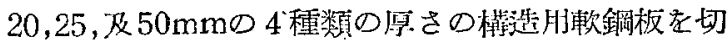


断実驗に使用した。その化学組成飞関しては分析の 結柴老次化示す. C0.19 0.26\%, Mn0.14 0.19\%， Si trace $\sim 0.06 \%, \mathrm{P} 0.020 \sim 0.027 \%, \mathrm{~S} 0.042 \sim 0.080$ $\%$

\section{9 . 鋼板の表面狀况}

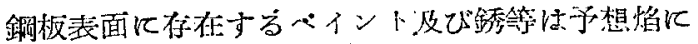

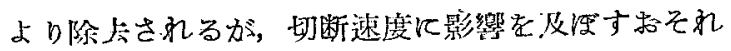
がきるので, 赤銹のひどいものはグラインダーで除 き，その他のものはガス，バーナーで表面を玔熱し さらにワイヤーブラシで銹を除ミして実驗に仳し た.

\subsection{0 切断速度}

切断速度をる程度早くすれば第1图に示すごと く迤れ（drag）を生じ始め，切断速度の早くなるに つ水て幄れる大をくる。

わが或で、通常ての䐅れのない(zero drag)切断 をする㑭慣があるが，アメリカでは経済的切断のた めとは记しろもる程度の㜊

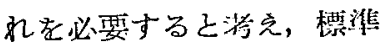
遅れ (standard drag)とい 万ものをもをめている忹ど で京る。從つて切断速度之 遲れとの関係をStr.フジれ とDiv.つ头几の雨教につけ て調べることにして切断速 度家大体ゼロ・ドラグから 切断できなくをる最阳速度 までの範囲に渡つて実際に

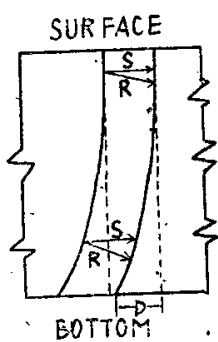

S: TIP SPEED S: TIP SPEED SPEED R: OXIDIZING SPEED

Fig. 1. Plate section and drag 切断してみることにした。

\section{3. 菑 驗 結 果}

\section{1 ノッ゙ルの切断酸素消費量の測定}

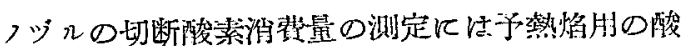

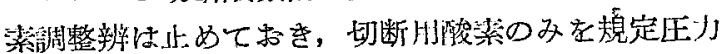

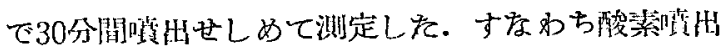

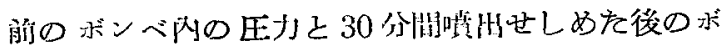
ンベ內の压力を测定すればボンべの容皘は㠺つてい

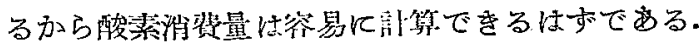

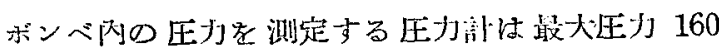

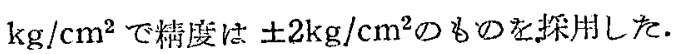

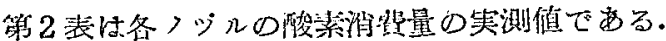

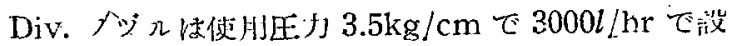

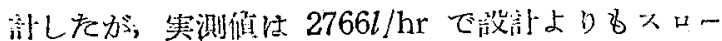

第 2 表 ノッ゙ルの單位時間当りの切断酸素消学量

\begin{tabular}{|c|c|c|c|c|c|}
\hline ッ゙ 2 & $\begin{array}{l}\text { 入口只口 } \\
\text { 酸溸压力 } \\
\left(\mathrm{kg} / \mathrm{cm}^{2}\right.\end{array}$ & $\begin{array}{l}0.5 \text { 時間 } \\
\text { た前後o } \\
\text { O)㞋力 } \\
\text { 韻出時 }\end{array}$ & 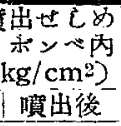 & $\begin{array}{c}\text { ボン心 } \\
\text { o)容蝵 } \\
\text { (l). }\end{array}$ & 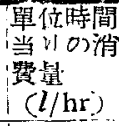 \\
\hline & 4 & 138 & 83 & 34.6 & 3806 \\
\hline A Piv. & 3.5 & 62 & 28 & 40.7 & 2766 \\
\hline
\end{tabular}

ト部の值径がやや小さくでき上つていたるのと思わ れる.そして出口の值径は設計值よりるやや大きか

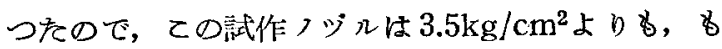

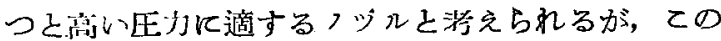

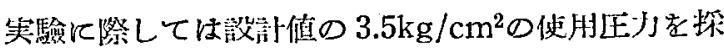
川しを。

\section{2 切断速度と遅れとの関係}

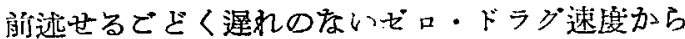
切断し得なくなる最高速度なでの切断を厚さ 12,20 ，

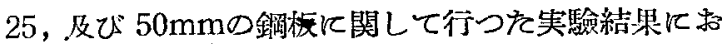
いてて，卯断速度と迤れとの関係第 3 表に示すでと くで新，てれを园示したるのが第2図 (a). (b). (c). (d), でむる.

第 3 表 各檑板厚に対する切断速度さ 遟れての関係 (奏測值)

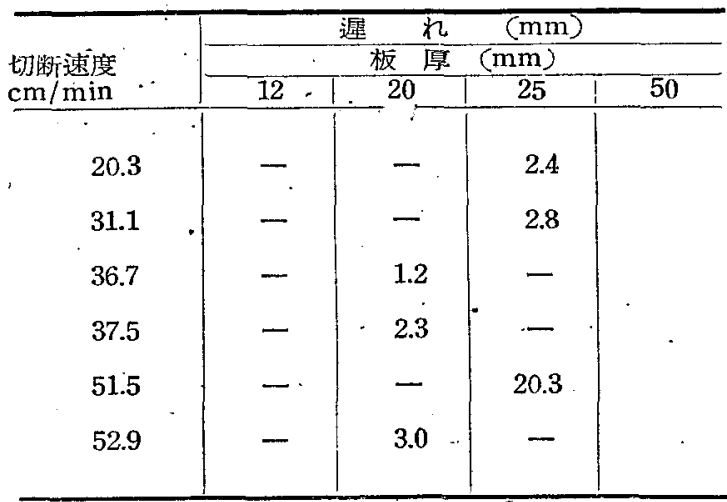

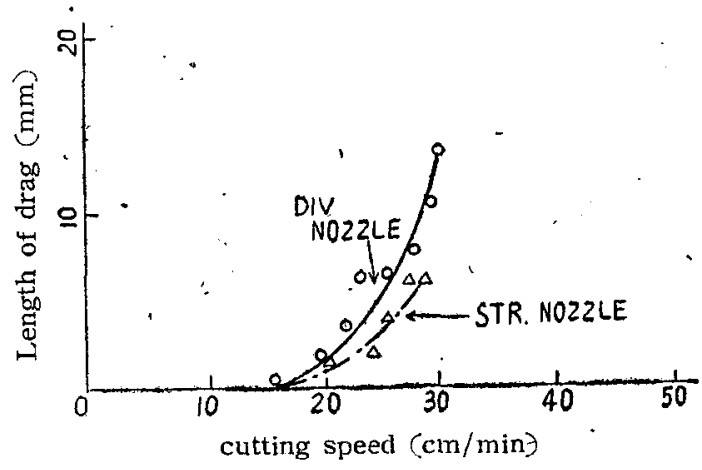

Fig. 2.-a Cutting speed and drag length THICKNESS OF PLATE : 50MM. 


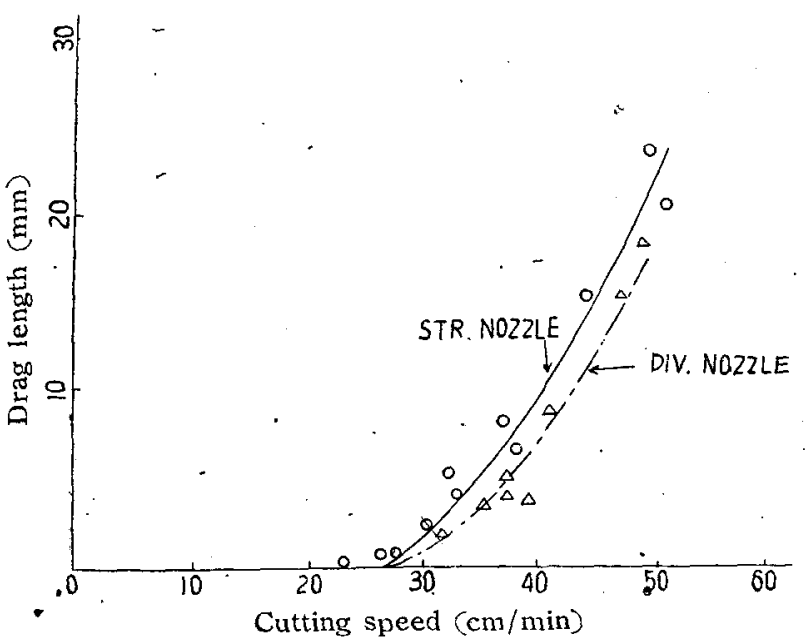

F ig. 2-k. Cutting speed and drag length THICKNESS OF PLATE : 25MM.

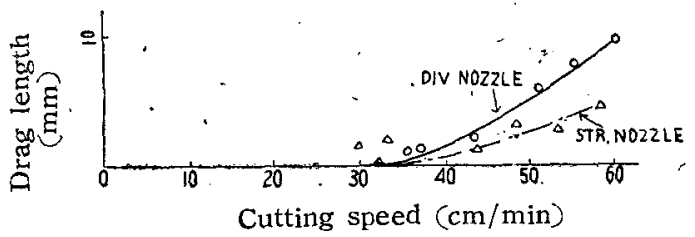

Fig. 2-c. Cùtting speed and drag length. THICKNESS OF PLATE : 20MM.

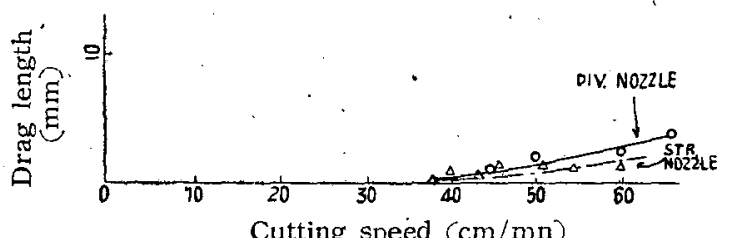

Fig. 2-d. Cutting speed and drag length. THICKNESS OF PLATE : 12MM.

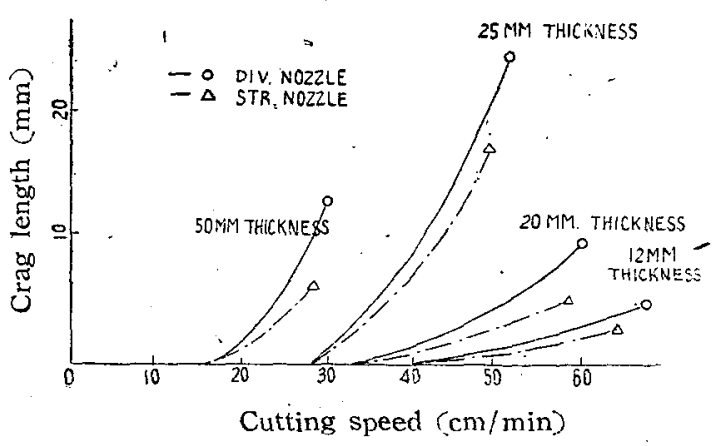

Fir. 2-e Cutting speed and drag length.

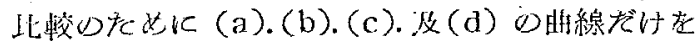

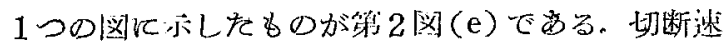

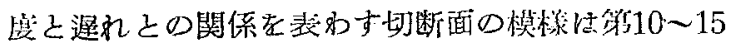

図の写責に亦されている。

\section{3 切断不可能となる場合の現象}

厚板の切断にホいては第 1 㓙に示すごさく， 鋼板の表面よりる.下面の才が酸化が崌れるため 切断連れ (drag) を生する. Div.のちがStr.よ 的同一切断速度に対して胵素量が少いためて

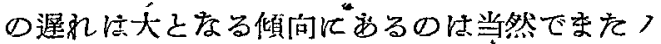

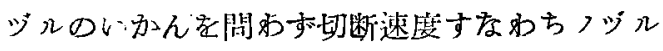
の移陲速度が大江なるつれてての遮れが大と

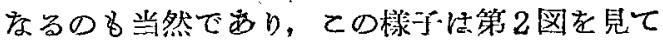
当明らかでする。從つて切断速度余り大にす

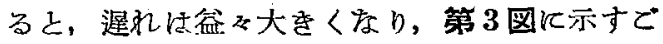

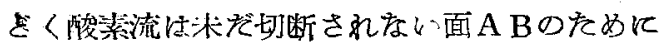
図の矢印のでとく斯げられ，切断面の下面に附着し たスラグを吹き我代すことるできず，そのスラグル

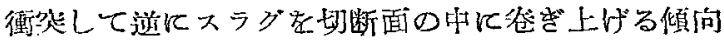
になり，切断面がスラダを作つてををなくなる代か ロでをく嫁に 注切断不可能 となる。欂板 ○埸命惊表面 と下证の盜琴

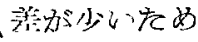
间一切断速度

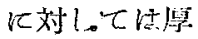

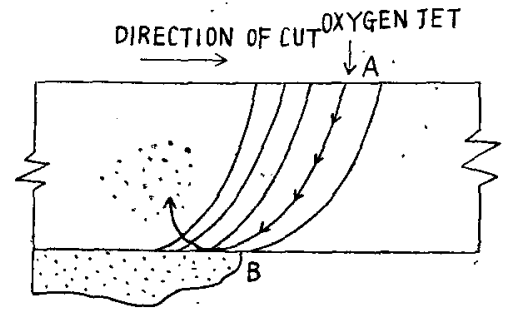

Fig. 3. Cutting speed too fast.

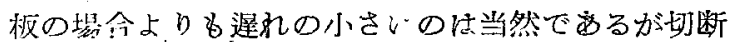

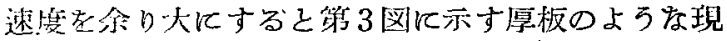

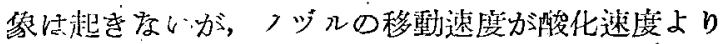
子大己なり切断不可能亡度る.

\section{$\mathbf{3 . 4}$ 切り海(kerf)の幅}

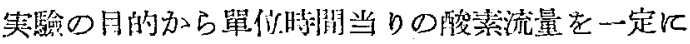

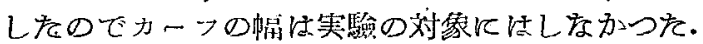

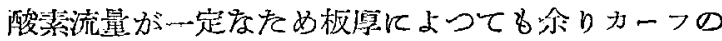

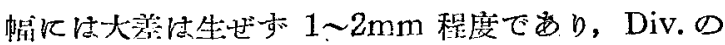

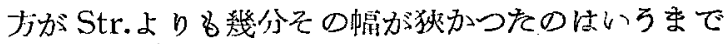
发子证。

\section{5 切断速度と板厚との関係}

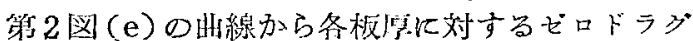

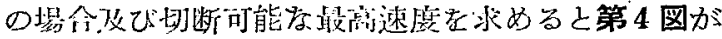
得られる。この図より明らからごとくゼロ，ドラグの

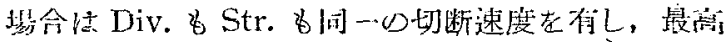

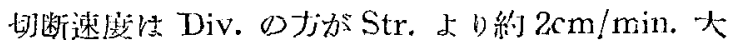

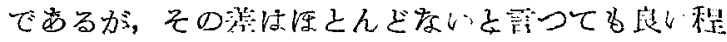




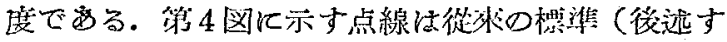

る) 索标生。

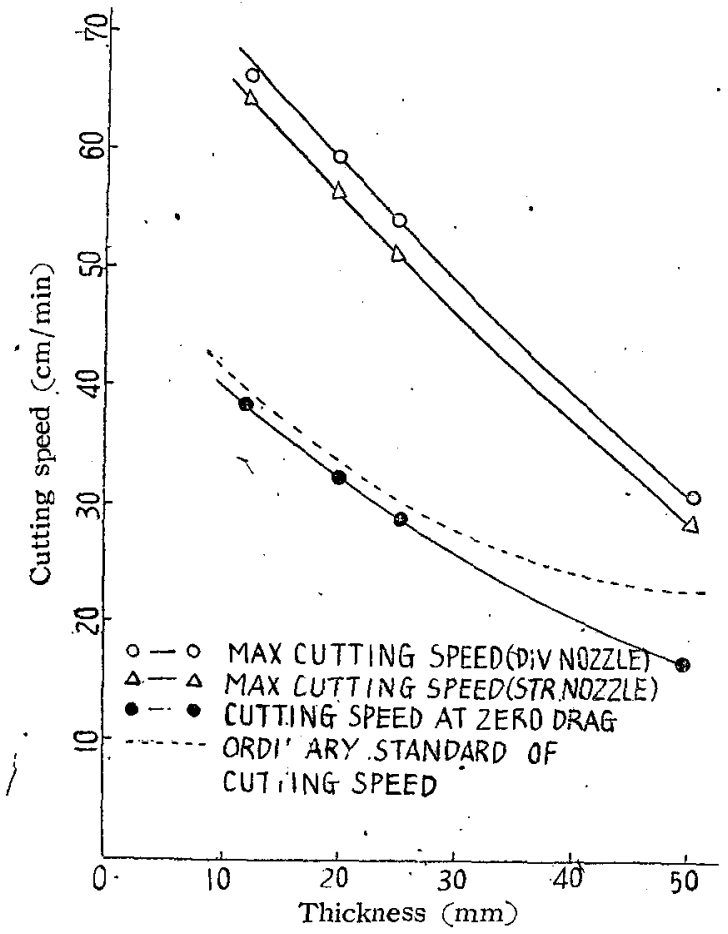

Fig. 4. Cutting speed and plate thickness.

\section{6 酸素消費量と板厚との関係}

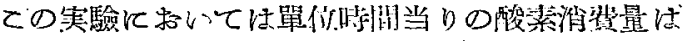
各ふのチツブルついては一定に保つをのであるが、

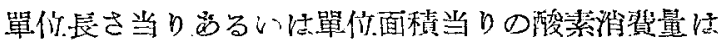

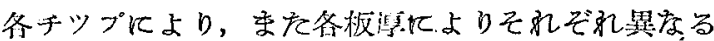

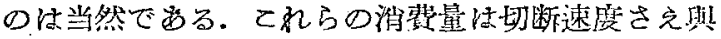

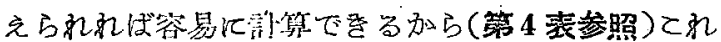
ら在図示す礼ば第 5 図及び第 6 図が得られる。これ

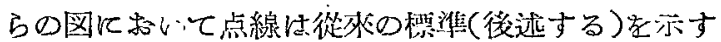
第。4 表 切断速度及酸素消費

\begin{tabular}{|c|c|c|c|c|c|c|c|c|c|}
\hline & \multirow[t]{2}{*}{$\begin{array}{l}\text { 板 } \\
\text { 厚 }\end{array}$} & \multicolumn{2}{|c|}{$\begin{array}{l}\text { 切断速度 } \\
\mathrm{cm} / \mathrm{min}\end{array}$} & \multicolumn{6}{|c|}{ 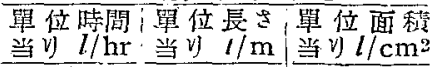 } \\
\hline & & Str. & Div. & Str. & Div. & Str. & Div. & Str. & IDiv. \\
\hline \multirow{4}{*}{ 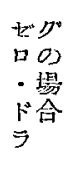 } & 12 & 38 & 38 & 3806 & 2766 & 167 & 121 & 1.39 & 1.01 \\
\hline & 20 & 32 & 23 & " & $"$ & 198 & 144 & 0.99 & 0.72 \\
\hline & 25 & 28 & 28 & " & " & 223 & 165 & 0.89 & 0.66 \\
\hline & 50 & 16 & 16 & $"$ & $"$ & $39 \%$ & 288 & 0.79 & 0.58 \\
\hline \multirow{4}{*}{ 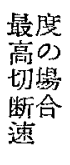 } & 12 & 64 & 66 & $"$ & $"$ & 99 & 70 & 0.83 & 0.58 \\
\hline & 20 & 58 & 60 & $"$ & $"$ & 109 & 77 & 0.55 & 0.39 \\
\hline & 25 & 50 & 52 & $"$ & $"$ & 126 & 89 & 0.50 & 0.36 \\
\hline & 50 & 28 & 30 & $"$ & " & 226 & 157 & 0.45 & 0.31 \\
\hline
\end{tabular}

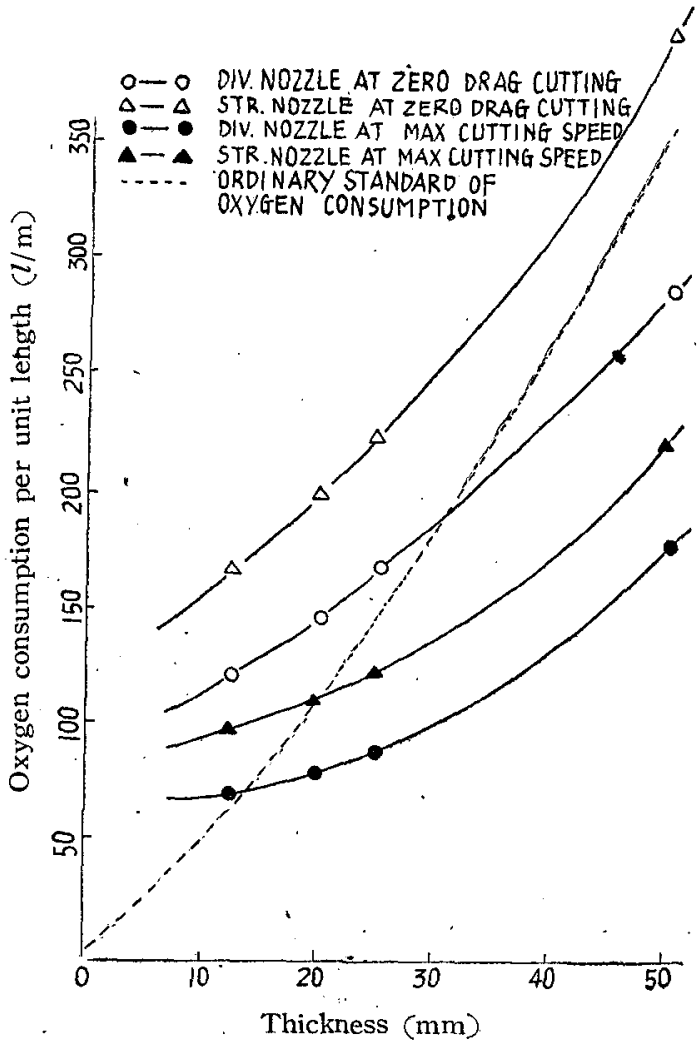

Fig. 5. Plate thickness and oxygen consumption per unit length.

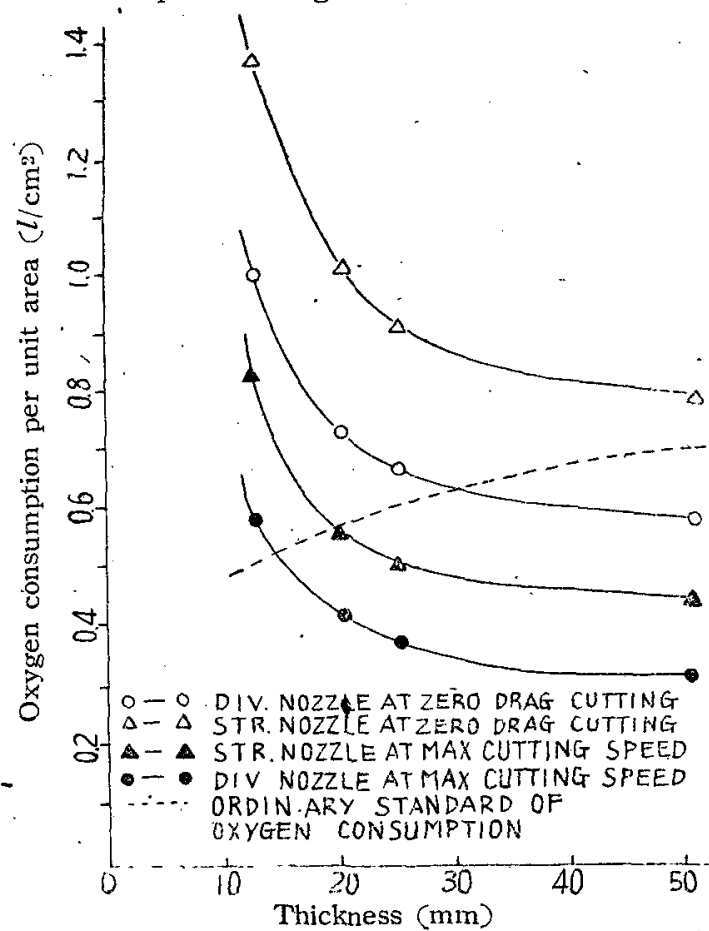

Fig. 6. Plate thickness and oxygen consumption per unit area. 


\section{4. 薑驗結果に對する考察}

実驗結果の項で远べをどとく(第4 図参照).Div. 及び Str.のッ゙ル汒々ロ，ドラグの場合の切断速度

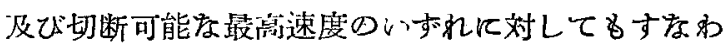
ち切断速度に䦎しては在とんき同一の性能を有し ていると言つても书言では疗りてての事は Div。と

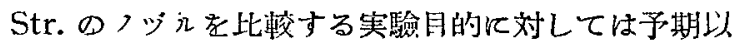
上の好都合なことで良つた。

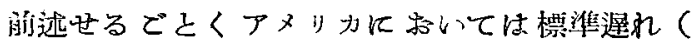

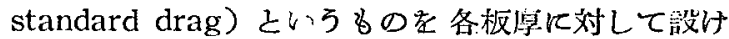
ている点より诺えて，実際の切断㖊つてはゼ口， ドラグでは切断速度は逮過ぎ，切断不可能々なる陵 界の最高速度では划断速度け早逈ざるのである。そ てで今実驗に供した Div. 及びStr.のノッれに対し 流量一定 (それぞれ 2766 及び $3806 \mathrm{l} / \mathrm{hr}$ ) で各板原

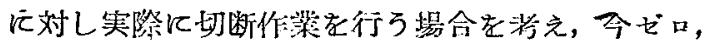

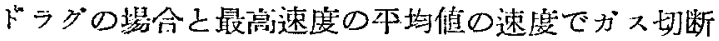
妾行うと假定する。す存わちStr. 及び Div. ○切断

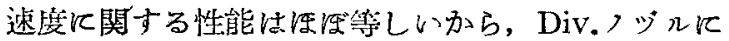

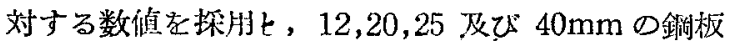
飞対しそれぞれ $52,46,40$, 及び $23 \mathrm{~cm} / \mathrm{min}$ の速展で 切断する場含について将えてみるてとにする。ての

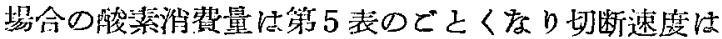
第 7 図に，單们長さ当り及び單仵面䅡当りの酸素消 掏量はそれぞれ第 8 图及び第9四に示すでとくなる

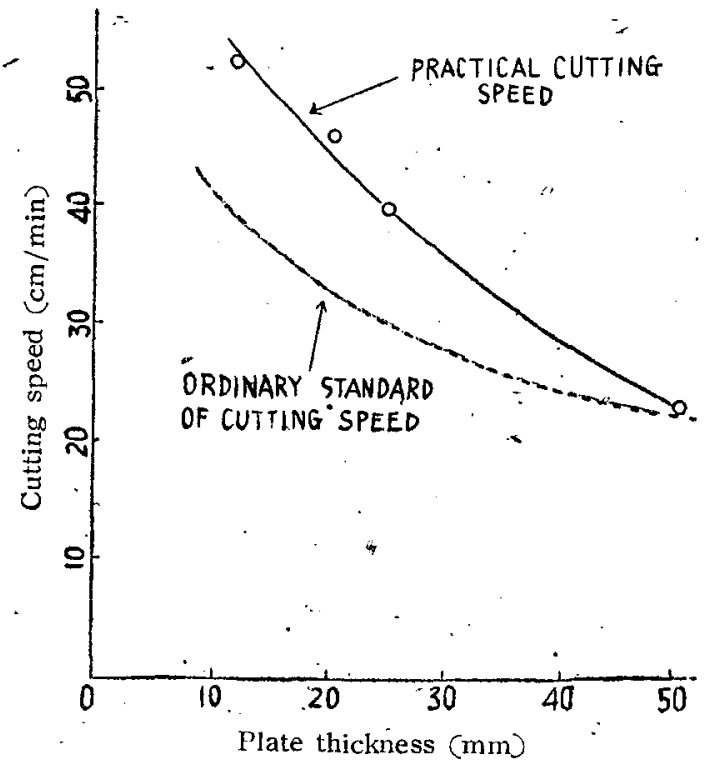

Fig. 7. Practical cutting speed obtained with nozzles used in the experiment

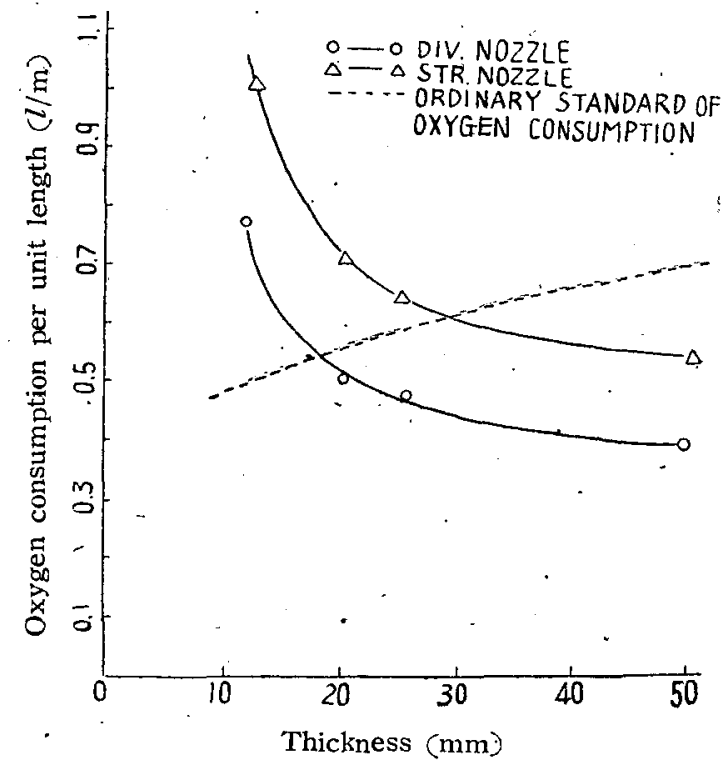

Fig. 8. Plate thickness and oxygen consumption per unit length. (Corresponding to cutting speed in Fig. 7)

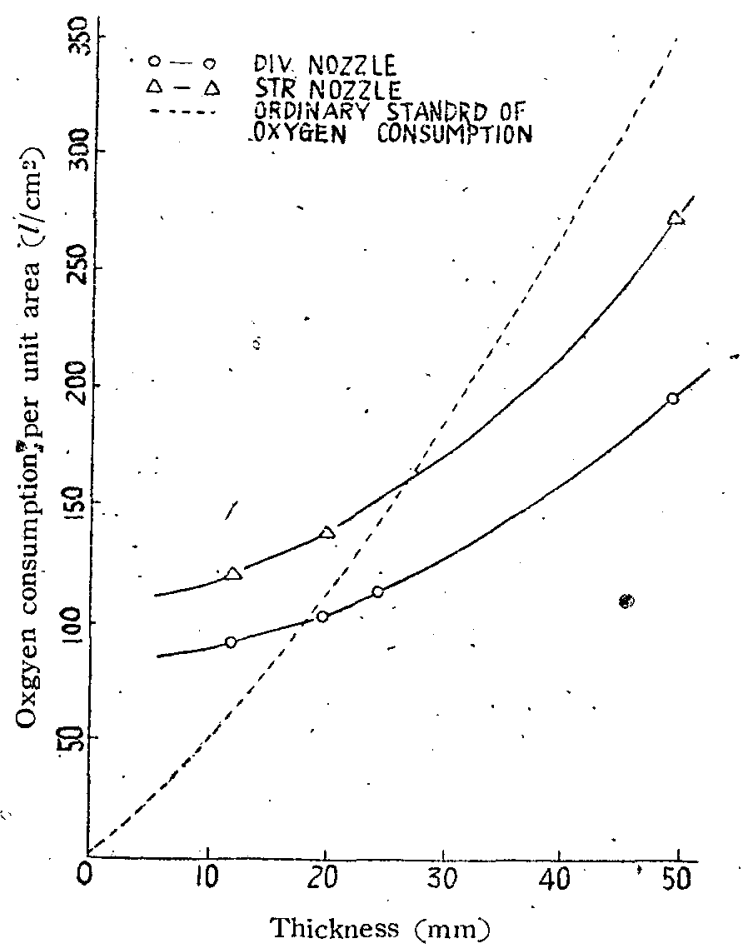

Fig. 9. Plate thickness and oxygen consumption per unit area (Corresponding to cuitting speed in Fig. 7) 


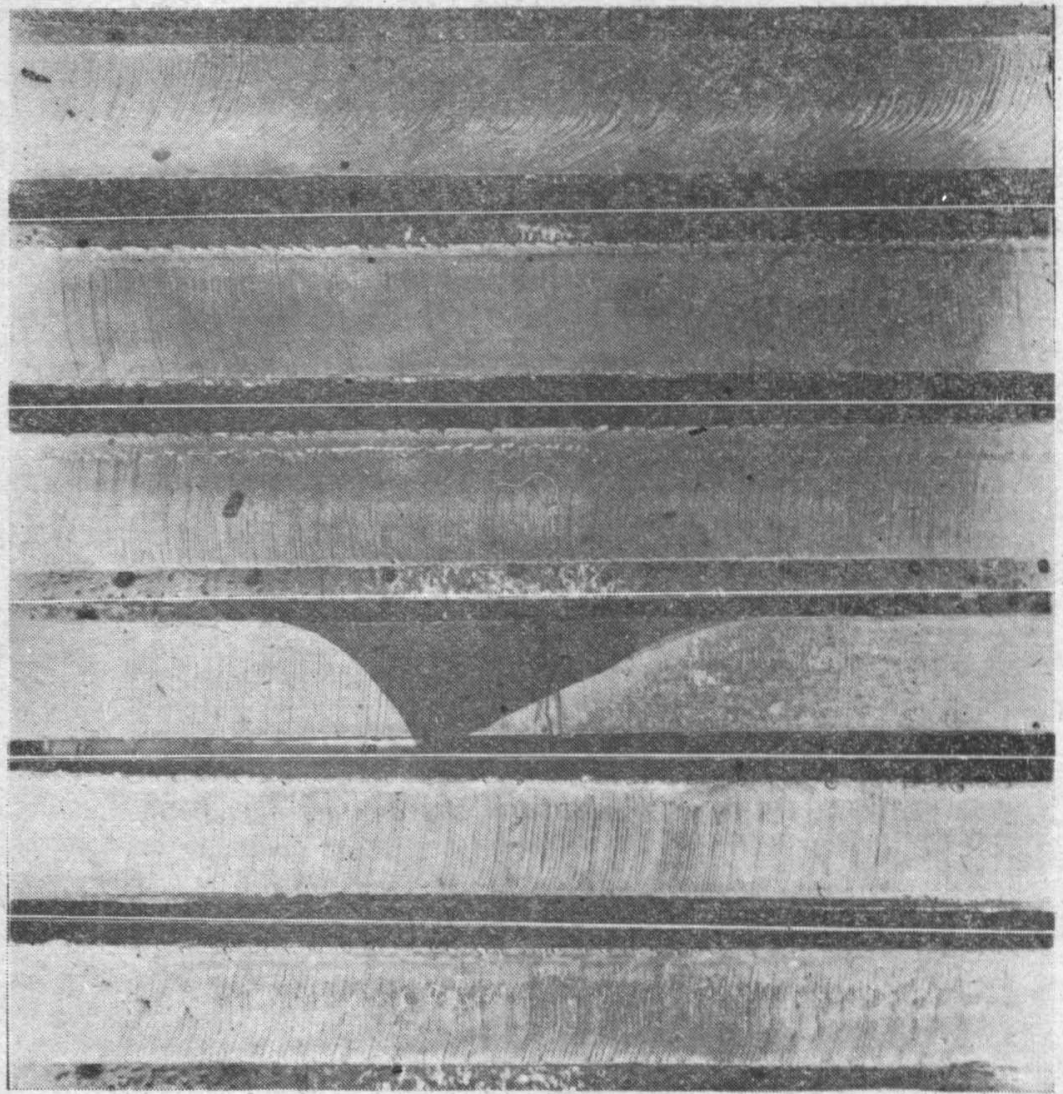

Fig. 10 Div. Nozzle

Plate thickness $25 \mathrm{~mm}$

Cutting speed $51.5 \mathrm{~cm} / \mathrm{sec}$ Drag length $20.3 \mathrm{~mm}$

Fig. 11 Div. Nozzle Plate thickness $25 \mathrm{~mm}$ Cutting speed $31.1 \mathrm{~cm} / \mathrm{sec}$ Drag length $28 \mathrm{~mm}$

Fig. 12 Str. Nozzle

Plate thickness $25 \mathrm{~mm}$

Cutting speed $26.3 \mathrm{~cm} / \mathrm{sec}$ Drag length $3.4 \mathrm{~mm}$

Fig. 13 Div, Nozzle

Plate thickness $20 \mathrm{~mm}$

Cutting speed $36.1 \mathrm{~cm} / \mathrm{sec}$ Drag length $\quad 1.2 \mathrm{~mm}$

\section{Fig. 14 Str. Nozzle}

Plate thickness $20 \mathrm{~mm}$

Cutting speed $37.5 \mathrm{~cm} / \mathrm{sec}$ Drag length $2.3 \mathrm{~mm}$

Fig. 15 Str. Nozzle

Plate thickness $20 \mathrm{~mm}$

Cutting speed $52.0 \mathrm{~cm} / \mathrm{sec}$ Drag length $3.0 \mathrm{~mm}$

第 5 表 流量一定した場合の実用切断速度已酸素消費量

\begin{tabular}{|c|c|c|c|c|c|c|c|c|c|c|c|}
\hline \multirow{3}{*}{$\begin{array}{c}\text { 板 厚 } \\
\mathrm{mm}\end{array}$} & \multirow{2}{*}{\multicolumn{2}{|c|}{ 切断速度 $\mathrm{cm} / \mathrm{min}$}} & \multicolumn{3}{|r|}{ t } & \multirow{2}{*}{\multicolumn{2}{|c|}{$\begin{array}{c}\text { 酸 素 } \\
\text { 單位長さ当v) }\end{array}$}} & \multirow{2}{*}{$l / \mathrm{m}$} & \multicolumn{2}{|c|}{ 量 } & \multirow[b]{2}{*}{$/ \mathrm{cm}^{2}$} \\
\hline & & & 單位 & 間当VJ & $l / \mathrm{hr}$ & & & & 單位 & 责当 V) & \\
\hline & Str. 度び Div. & 標集 & Str. & Div. & 標淮 & Str. & Div. & 標 榫 & Str. & Div. & 標 準 \\
\hline 12 & 52 & 39.4 & 3806 & 2766 & 1430 & 122 & 89 & 61 & 1.02 & 0.74 & 0.51 \\
\hline 20 & 46 & 32.6 & " & " & 2200 & 138 & 100 & 113 & 0.69 & 0.50 & 0.57 \\
\hline 25 & 40 & 29.4 & " & " & 2650 & 158 & 115 & 150 & 0.63 & 0.46 & 0.60 \\
\hline 50 & 23 & 22.4 & " & " & 4780 & 276 & 200 & 355 & 0.55 & 0.40 & 0.71 \\
\hline
\end{tabular}

一般に各種の板厚に対する切断速度及び酸素消费 量は次式で示される.

$$
\begin{aligned}
& S=11.5 T^{(-0.3869)} \\
& V=95.5 T(-0.8425)
\end{aligned}
$$

但L $S$ : 切断速度 (in $/ \mathrm{min})$

$V: 1$ 時間当りの陵素消費量

(cub.ft/hr)

\section{$T:$ 板厚 (in)}

(1)式及び(2)式を用いて計算した切断速度及酸素消 費量は第 5 衰に示されており、、第4～9図には点線 で示しておいた。実驗の目的からら板㝠のいかんれが かから政素流量を一としたために，20 $\mathrm{mm}$ 以下の 清板に対して性酸素の流量が多過ざるので從來の標
準に比ぺて切断速度がそれだけ大となるに反し（第

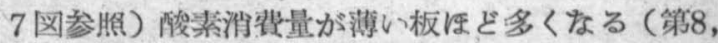
9図参照) 傾问がみられるのはをしろ当然である.

第8図及び第9図の陵素消䩀量をみるとDiv.の方 がStr.よりもはるがすぐれた性能を有しているは すなわお Str. つッ゙は $50 \mathrm{~mm}$ 以外の板に対して. 消费量が標潐值よりる大であり，Div。ノッ゙は 12 $\mathrm{mm}$ 以外の板に対しては標準値よりる小である. 第 8 図の單詣浐さ当りの酸素消費量の曲線が板厚が答 になつてる消費量の零の点に集まりそうにないのは 板厚が溥くなると從ひ酸素量が益く過剩となるため でる. 第9図の單仿面栍当りの酸素消费量は從來 の標潐とは逆に板厚が薄くなると從い大となつてい 
るのる上記の理由による。一般化鐵が切断酸素に上

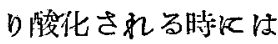

$$
3 \mathrm{Fe}+2 \mathrm{O}_{2} \longrightarrow \mathrm{Fe}_{3} \mathrm{O}_{4}
$$

の化学反雇が起るすのとわわているが,

$$
2 \mathrm{Fe}+\mathrm{O}_{2} \longrightarrow 2 \mathrm{FeO}
$$

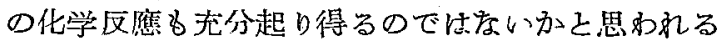
今切り箠の幅を $2 \mathrm{~mm}$ とするなら單们面程当りの 酸素の必雷量は(3)式及び(4)式によればそれぞれ 0.416 及び $0.312 l / \mathrm{cm}^{2}$ となり，乙の後者の值は第 6 図より明ら方疼ごとくDiv。を对いて切断し得る最

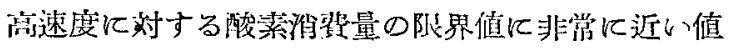

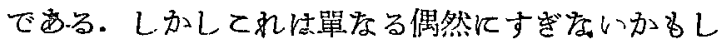

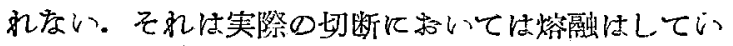
るが米だ酸化されていない鐵が酸素流で吹き飛ばさ れることるするのですなわち切断される時汇鋼板が ら失われは鐵はすべて陵化されているとは限らす，

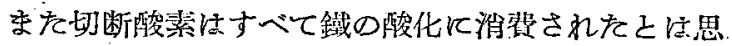
わ机ないのて，切断現像を鐵が(4)式また结(3)式に

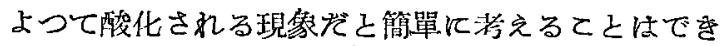
ないからである。

切断速度の性能の点飞括いて Div. と Str. と同一

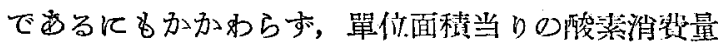

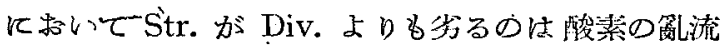

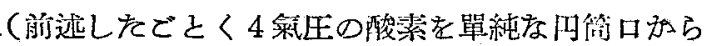

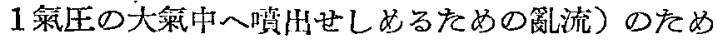
飞相当量の酸䒺が無駄をなつていてとを示してい るに過焉ない: すなわち Str.の 3806l/hr と対し Div. は $2766 \mathrm{l} / \mathrm{hr}$ で方るから酸素渻然量は $27.4 \% の$ 節約が可能学わけでめる。

最後にこの実驗から得られた結論を们举すれば次 のでとくである。

（1）切断速度飞関する性能が等しい是合には，そ の板厚のいかんを間わ和 Din.フジルの方がStr.ノ

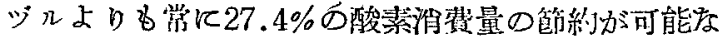

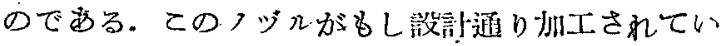
たならげ切断能率をさらに改善せしめ得るてとが期 待される。

（2）ての実驗では酸素王力を一定にしたをめ 20 $\mathrm{mm}$ 以下の薄板の切断に活陵素量が過剩ですつて不 適当であつたが，25mm 以上の曆い板に対しては單

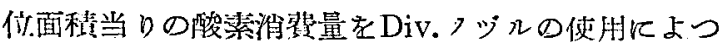
て約 $0.3 l / \mathrm{cm}^{2}$ にまで下げる事ができた。

（3）Div.フッ几结酸装のE力を速度飞変化せしめ 得るので，包り溝の幅の狹い美麗な切断面が得られ

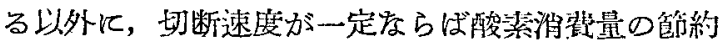
が，消费量が一定なら河断速度の境大が期待され 得るのでるる。

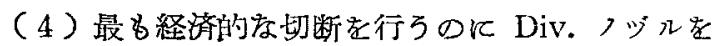

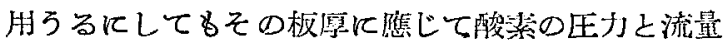
をいが選んだ Div.フッ゙ルを探用すべきが関し

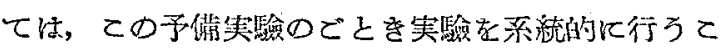
とによつて明らかてなし得ることが判つた。

な祘ての実驗でチツプの予熱焰を一定にしたので その影響を知ることはできなからを济，予熱焰と，

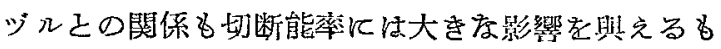
のと思われるので今後研笲老進めたいと思つてい る.

\section{5.あとがき}

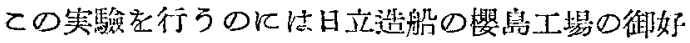

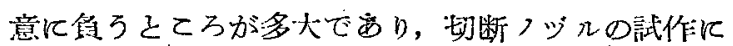

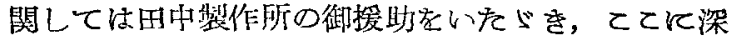

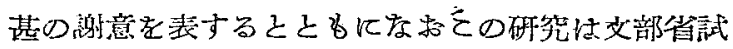
驗硛究費交附を受けていること僅しんで附記する 次第である。 